Persp. Teol. 37 (2005) 31-54

\title{
ECUMENISMO E INSTITUIÇÃO ECLESIAL
}

\author{
Mario de França Miranda SJ
}

RESUMO: O presente estudo considera a dimensão institucional da Igreja com o objetivo de colaborar no movimento ecumênico. A realidade transcendente e divina da Igreja só existe de fato em sua realidade institucional e histórica, a saber, na comunidade dos fiéis com tudo o que isto implica. Enquanto comunidade humana na história, ela se encontra em contínua interação com o respectivo contexto sociocultural, apresentando ao longo dos séculos configurações diversas para garantir sua identidade de sacramento da salvação de Jesus Cristo. Mesmo reconhecendo as questões ainda pendentes entre as confissões cristãs, esta reflexão reforça o ideal de uma Igreja una na diversidade das confissões.

PALAVRAS-CHAVE: Igreja, instituição, ecumenismo, história da Igreja, Espírito Santo.

ABSTRACT: This study considers the institutional dimension of Church in order to collaborate with the ecumenical movement. In fact, the divine and transcendent reality of the Church only exists in its institutional and historical reality, that is, in the faithful community with all its implications. While human community in history, the Church remains in constant interaction with its socio-cultural context, presenting throughout the centuries diverse configurations to guarantee its identity as sacrament of Christ's salvation. Recognizing some open questions among the Christian confessions, this reflection emphasizes the ideal of one Church in the diversity of confessions.

KEY-WORDS: Church, institution, ecumenism, Church history, Holy Spirit. 


\section{Introdução}

advento da modernidade desfez um imaginário social unitário e hegemônico que vigorou até a Idade Média, pois a emancipação progressiva de vários setores do saber deu nascimento às ciências exatas, sociais e humanas, com suas respectivas perspectivas de leitura da realidade. A fé cristã que aparecia como a chave de leitura dominante e onipresente acaba relegada a ser mais um setor desta sociedade pluralista. A reação da Igreja diante da modernidade emergente foi de desconfiança e hostilidade por ver ameaçada sua linguagem tradicional, suas instituições centenárias, sua influência social, numa palavra, seu modo de viver e compreender a fé cristã. Daí a tentativa de dar as costas à sociedade, de construir seu próprio mundo católico, de não se deixar interpelar pelas conquistas científicas ou pelas novas compreensões da realidade.

A revelação cristã concerne o próprio mistério de Deus e jamais poderá ser enquadrada nos limites da razão humana. Ela afirma uma experiência de salvação, que nos chega através dos testemunhos da Igreja apostólica, e não através de sistematizações que se legitimariam por terem passado no crivo da razão suficiente. Contudo, a ênfase no que supera o racional por balbuciar o mistério de Deus, como a encarnação do Verbo ou a morte e ressurreição de Jesus, não pode deixar de lado a dimensão humana deste mistério, sob pena de o tornar não significativo para a humanidade. Respeitar esta última dimensão sempre apresenta um risco de redução ou deformação do dado revelado. Entretanto, o passo deve ser dado, em direção a uma maior luminosidade da fé que parta desta mesma fé como dom de Deus.

O primeiro encontro da modernidade com a religião já se deu na Grécia, através da crítica filosófica aos mitos e divindades de então. Alguns consideram a tensão entre Boaventura e Tomás de Aquino, ou entre a teologia franciscana, alimentada pelo mistério da cruz, e a teologia tomista, marcada pela busca de uma inteligência da fé, como reações diversas da fé cristã diante de uma modernidade prematura preanunciando a outra, que apareceria séculos mais tarde ${ }^{1}$. O clima tenso entre o pensamento liberal e a Igreja católica impedirá o conhecimento mútuo, o qual possibilitaria um diálogo fecundo para ambas as partes em litígio. A rejeição do assim chamado modernismo deixou sem resposta as novas questões postas pelas ciências e enfraqueceu a credibilidade da fé em ambientes mais cultos.

O Concílio Vaticano II representa um ponto final neste divórcio entre Igreja e sociedade moderna. Sua pretensão última foi realizar um aggiornamento, a saber, proclamar a salvação de Deus numa linguagem que fosse entendida e significativa para os nossos contemporâneos. Seus

${ }^{1}$ G. LAFONT, Histoire théologique de l'Église catholique, Paris, 1994 (LAFONT 1), p. $194 \mathrm{~s}$. 
textos, mesmo os mais dogmáticos, como a Constituição Lumen Gentium (LG)e a Dei Verbum (DV), buscam intencionalmente expressões bíblicas e descritivas, que melhor façam aflorar a dimensão histórico-salvífica da revelação. A constituição apostólica Gaudium et Spes retoma o diálogo com o mundo moderno e leva a Igreja a assumir seu papel histórico na construção do futuro da humanidade. Sabemos que a repercussão efetiva de um concílio pode ser bem variada, sendo que o Vaticano II não constitui uma exceção. Alguns aspectos foram fecundos nos anos posteriores, outros se viram relegados ao silencio na vida eclesial.

A reflexão teológica pós-conciliar, entretanto, manteve-se na linha aberta pelos teólogos e bispos responsáveis pelos textos conciliares. Este presente estudo pretende chamar a atenção a partir desta perspectiva teológica, aberta ao desafio da modernidade, para o setor da eclesiologia, de enorme importância para o ecumenismo. Cada vez mais se constata o acordo entre as Igrejas cristãs no que concerne propriamente a salvação de Jesus Cristo, enquanto permanecem as diferenças no que diz respeito aos meios para esta mesma salvação. E, sem dúvida alguma, a Igreja em sua autocompreensão e, sobretudo, em sua estrutura institucional, representa hoje um obstáculo à união dos cristãos. Assim, buscaremos examinar mais cuidadosamente este aspecto institucional da Igreja, seja a partir de uma perspectiva sociocultural, seja a partir da própria história da Igreja, para podermos numa parte final avançar algumas sugestões que contribuam para uma maior união entre as Igrejas. Nosso objetivo não vai além do âmbito da teologia fundamental, de tal modo que não pretendemos entrar em questões concretas de teologia confessional.

\section{O paradigma de Calcedônia}

O grande paradigma para falarmos de Deus, de sua revelação, de sua encarnação, de sua ação salvífica, da comunidade cristã e dos sacramentos é o importante legado que nos deixou o Concílio de Calcedônia. Em Jesus Cristo as duas naturezas, a saber, a divina e a humana, que constituem uma única pessoa, não se confundem nem se separam (inconfuse et indivise). Por ser o humano o que nos é mais diretamente acessível, será através dele que chegaremos ao divino. As tentativas incipientes de expressar a pessoa de Jesus Cristo por parte da primeira geração de cristãos confirmam o que dissemos. De fato, as cristologias presentes no Novo Testamento partem sempre do Jesus histórico, de suas palavras e ações, para alcançar então sua divindade. E num estágio mais avançado de reflexão e de compreensão da pessoa de Cristo, o Jesus histórico não desaparecerá."O que era desde o princípio, o que ouvimos, o que vimos com nossos olhos, o que contemplamos e nossas mãos tocaram do Verbo da vida (...), nós vo-lo anunciamos também a vós" (1Jo 1,1-3). 
A encarnação do Verbo eterno de Deus significa que assumiu a condição humana e que entrou na história, submetendo-se às suas leis, seus pressupostos, suas lógicas, suas limitações, suas peculiaridades. Deste modo, mesmo reconhecendo em Jesus Cristo a plenitude da verdade e da salvação, temos que conceder que esta plenitude não aflora explicitamente em toda a sua amplitude nos relatos neotestamentários. Aqui é fundamental o advérbio empregado por Paulo: "Nele habita corporalmente toda a plenitude da divindade" $(\mathrm{Cl} 2,9)$. Pois esta plenitude, embora manifestando-se como tal, encontra-se num contexto sociocultural bem determinado, que permitirá e simultaneamente limitará sua expressão². Sem dúvida alguma, a cultura semita e a sociedade concreta onde nasceu o Filho de Deus não deixarão de condicionar as ações e as falas de Jesus, permitindo-lhe, por outro lado, ser entendido, acolhido e seguido por seus contemporâneos.

Além disso, e esta é outra razão de peso, embora confessemos (e devamos fazê-lo) ser Jesus Cristo a plenitude da verdade de Deus, isto não implica que já a tenhamos perfeitamente. Já Paulo nos alertava para os limites de nosso conhecimento sobre coisas da fé, conhecimento este como num "espelho e de modo confuso" (1Cor 13,12). Daí a afirmação taxativa: "A plenitude da verdade recebida em Jesus Cristo não dá aos cristãos, individualmente, a garantia de terem assimilado de modo pleno esta verdade" (Diálogo e Anúncio 49). E poderíamos acrescentar: e nem mesmo coletivamente. Pois a tensão entre o "já" e o "ainda não" acompanha sempre nossa compreensão da verdade revelada. Por isso mesmo na tradição dos Apóstolos "cresce, com efeito, a compreensão tanto das coisas como das palavras transmitidas", de tal modo que a Igreja "tende continuamente à plenitude da verdade divina" (DV 8).

Uma conclusão muito importante subjaz a esta afirmação do Concílio Vaticano II: só existe Palavra de Deus, só existe revelação, quando a autocomunicação de Deus chega a sua meta, sendo acolhida pelo ser humano. Portanto a aceitação na fé é parte constitutiva da realidade da revelação de Deus. Sem a fé, os feitos históricos de Deus em favor de seu povo estariam mudos, a proclamação evangélica seria mera palavra humana e a verdade última sobre Jesus Cristo nos seria desconhecida. Deste modo, $a$ resposta da fé a Deus, possibilitada pelo mesmo Deus, pertence ao próprio conteúdo do que é a Palavra de Deus para nós. E por essa mesma razão devemos afirmar não estar completa a revelação sem a Igreja, enquanto comunidade dos que crêem ${ }^{3}$.

${ }^{2}$ E. SCHILLEBEECKX, L’histoire des hommes, récit de Dieu, Paris, 1992, p. 163: "La face humaine de Jésus révèle le visage divin non seulement selon des contours bien definés, mais elle le cache aussi, puisque c'est une révélation de l'ineffabilité divine au travers de l'expression réellement humaine, historique, et donc contingente et limitée, qu'en est Jésus".

${ }^{3}$ A. DULLES, Models of Revelation, New York, 1996, p. 220. 
Daí a seqüência de cristologias que se sucederam ao longo da história da Igreja e que necessariamente continuarão a se suceder, desde que nossos pósteros acolham na fé a mesma autodoação de Deus que acolhemos. Eles estarão em comunhão conosco na mesma fé em Jesus Cristo, embora as respectivas configurações históricas devam diferir da nossa pelos diferentes contextos socioculturais em que estarão vivendo e pelos desafios que estarão enfrentando. Embora reafirmando sempre a verdade que é Jesus Cristo, ao acolher as expressões passadas já reconhecidas como autênticas pela comunidade eclesial, a mudança do contexto exige novos insights e formulações para que esta verdade não seja deformada em sua compreensão.

Aqui chegamos à outra conclusão deveras importante. A revelação não só não pode prescindir da fé da comunidade eclesial, como ainda não pode ignorar o horizonte cultural onde vive esta mesma comunidade. Sob pena de não ser simplesmente entendida, sob pena de não ser revelação sem mais. Toda teologia, enquanto fé que busca compreender-se, sempre implica uma antropologia. Não podemos negar este substrato humano, sempre presente nas expressões doutrinais, nos preceitos éticos ou nas estruturas jurídicas encontradas na Igreja. Contudo, também não podemos negar que um certo monofisitismo, reagindo a uma tendência nestoriana, entrou na consciência de fé da Igreja, deixando de certo modo esquecido o humano ao se falar do divino.

Este fato pode levar a um supranaturalismo desencarnado que acaba por absolutizar indevidamente formulações, práticas e normas eclesiásticas, por não considerar o contexto sociocultural e histórico onde nasceram. Mais uma vez o sábio ensinamento de Calcedônia deve guiar nossa reflexão: sem mistura (inconfuse), mas também sem separação (indivise). Esta orientação não concerne à cristologia somente, pois atravessa toda a revelação, por estar presente na fé, dom de Deus acolhido e fundamento de todo o resto.

Os estudos sobre a base antropológica da ação salvífica de Deus na história humana, motivados sem dúvida pela modernidade, provocaram já séculos atrás uma nova abordagem dos textos bíblicos, hoje tema obrigatório em qualquer estudo sério da Sagrada Escritura. Na mesma linha surgiram as pesquisas cristológicas e trinitárias, fazendo emergir o substrato humano, histórico e lingüístico, o qual explica, naturalmente em parte, por se tratar de ação de Deus, as expressões utilizadas no Novo Testamento e nos primeiros grandes Concílios para comunicar o que experimentavam os cristãos desta atuação divina. Ainda resultantes da mesma problemática situam-se os estudos levados a cabo pela nouvelle théologie em torno da graça de Deus. Justapor graça à natureza (ou à pessoa, como hoje dizemos) significa confinar a graça divina ao âmbito do sagrado, limitando, quando não eliminando, sua atuação na realidade humana da história, da sociedade, do trabalho, relegados ao âmbito do profano, moedas sem valor para a vida eterna. O divórcio entre Igreja Católica de um lado e, de outro, a cultura, a sociedade, a construção da história, traço marcante da fisionomia 
eclesial dos últimos séculos, tem aqui, sem dúvida, uma de suas causas mais significativas.

Todo este esforço para evitar um supranaturalismo rejeitado pela consciência moderna, e tornar a fé cristã mais acessível a esta mesma consciência, vai ficar conhecido como o giro antropológico na teologia. Não se pode falar de Deus sem falar do homem e não se pode falar do homem sem mencionar Deus. Karl Rahner ${ }^{4}$ é, neste particular, o nome mais citado, por ter elaborado em sua teologia transcendental esta preocupação comum de sua geração. Trabalho pioneiro ao lado de outros de não menor valor como atestam as obras de E. Schillebeeckx ${ }^{5}$, P. Tillich ${ }^{6}$, B. Lonergan ${ }^{7}$, para só mencionar alguns nomes. A abertura do Concílio Vaticano II ao mundo de hoje confirmará a tendência dominante de que não se pode pensar e elaborar teologia prescindindo do ser humano em toda sua amplitude e complexidade.

Ultimamente a própria realidade da Igreja, como mistério e comunidade humana, vem também sendo objeto de estudos que buscam não só esclarecer sua origem, mas ainda por que assumiu esta configuração concreta que hoje conhecemos. Fatores de cunho sociocultural, bem como causas históricas emergem nestes estudos. Poderíamos começar nossa reflexão pela própria história da Igreja e, num segundo passo, examinar como em sua evolução estão presentes os necessários e universais componentes de qualquer comunidade humana. Preferimos fazer o caminho inverso: partir dos dados socioculturais e, posteriormente, examinar como eles estão presentes e atuantes, ao longo da história da instituição Igreja. Teremos que nos contentar com alguns exemplos, pois este estudo é de cunho fundamental e não histórico. Numa parte conclusiva veremos o que nos pode ensinar esta abordagem antropológica da realidade eclesial em vista do ecumenismo.

\section{A Igreja na perspectiva sociocultural}

\section{Uma leitura legítima e necessária}

Esta leitura da Igreja como mistério e instituição decorre da virada antropológica acima mencionada. Só que o ser humano é visto não só em sua dimensão filosófica, mas também como ser histórico necessariamente inse-

\footnotetext{
4 "Theologie und Anthropologie", Schriften zur Theologie VIII, Einsiedeln, 1967, p. 4365; Grundkurs des Glaubens, Freiburg, 1976.

5 Jesús: la historia de un Viviente, Madrid, 1981; Cristo y los cristianos: gracia y liberación, Madrid, 1983.

${ }^{6}$ Systematic Theology, Chicago, I, 1951; II, 1957; III, 1963.

${ }^{7}$ Insight: a Study in Human Understanding, New York, 1957; Method in Theology, New York, 1972.
} 
rido num contexto sociocultural concreto. É fundamental fazer emergir esta dimensão do ser humano ao acolher a interpelação gratuita de Deus juntamente com outros, constituindo assim uma comunidade de fiéis. A Palavra de Deus não cai num vazio antropológico nem num ser humano abstrato, como algo que vem totalmente de fora. Por aceitar esta afirmação não devemos temer os dados das ciências humanas e sociais, embora devamos examiná-los sempre criticamente. Não foi este, aliás, o esforço gigantesco realizado por Santo Tomás de Aquino ao se deparar com a filosofia de Aristóteles, avaliando e criticando suas teses e as aproveitando para a compreensão da fé cristã? A aprovação de sua obra pela Igreja legitima assim nosso estudo.

Afirmar que a Igreja é o Povo de Deus, o Corpo de Cristo, o Templo do Espírito Santo, que ela é Comunhão, é sem dúvida correto, pois oferece uma visão desta comunidade humana a partir de Deus. Pois estas expressões têm sua fonte no testemunho do Novo Testamento, na própria revelação de Deus. Podemos também afirmar que elas têm suas raízes numa realidade teologal vivida e experimentada pelos primeiros cristãos. Também não devemos omitir que a Igreja existe por pura iniciativa de Deus, primeira, gratuita, fundante. Jamais uma leitura da Igreja que prescinda da fé conseguirá determinar corretamente sua identidade. Toda abordagem sociológica ou histórica da mesma deveria estar consciente disso. Legítimas em seu nível epistemológico, elas são sempre compreensões penúltimas quando se trata da Igreja. O reducionismo sociológico se arvora uma competência que não tem, estando bastante difundido em alguns ambientes.

Porém, por outro lado, não se deve esquecer ser a Igreja uma comunidade humana, sujeita aos imperativos e leis de qualquer grupo de seres humanos que pretendam se constituir como comunidade. Naturalmente a iniciativa é de Deus, mas não haveria Igreja sem a resposta humana, assim como a revelação de Deus chega à sua realização plena na resposta da fé. A Igreja é esta resposta humana em chave social, é a comunidade que acolhe a iniciativa de Deus na fé, na esperança e no amor. Na própria caracterização da Igreja entram a compreensão do gesto de Deus e a liberdade de acolhê-lo como tal. Não se nega com isso a dimensão transcendente desta comunidade, mas também não se reduz a mesma a abstratas imagens teológicas ${ }^{8}$.

A experiência salvífica do indivíduo, realizada sempre num contexto comunitário que a identifica, tende naturalmente a se expressar e se transmitir para outros através de doutrinas, de ritos e práticas, de organizações

${ }^{8}$ J.A. KOMONCHACK, Foundations in Ecclesiology, Boston, 1995, p. 151: "Against the holier abstractions, it is necessary to insist that the Church is not the divine initiative itself, but the human social response to God's grace and word". 
sociais, de funções e papeis, que significam a institucionalização desta experiência primeira. Toda religião busca se institucionalizar para poder perdurar. Este processo está a serviço do encontro salvífico do ser humano com Deus, como mediação que o facilite e o promova. A instituição só se torna algo negativo quando se arvora em fim, quando não mais remete ao transcendente que a fez nascer, quando busca apenas se perpetuar, quando deixa de ser simples mediação religiosa'.

A questão de fundo é exatamente articular como a iniciativa de Deus em Jesus Cristo se realiza concreta e historicamente na comunidade humana, pois só aí temos o que seja o Povo de Deus, o Corpo de Cristo e o Templo do Espírito, ou a Comunhão como obra do Espírito Santo. Portanto, não podemos deixar de fora da definição da Igreja os seres humanos concretos, inseridos num contexto cultural, vivendo situações históricas, desenvolvendo qualidades e enfrentando desafios próprios, em sua fragilidade e pecaminosidade. Caso contrário, a experiência que fazem nossos contemporâneos com a Igreja estaria bem distante das afirmações teológicas teóricas sobre a mesma ${ }^{10}$. Naturalmente não cabe às ciências humanas se ocuparem com os dados propriamente revelados, mas sim com as categorias inerentes a qualquer comunidade humana, nas quais estes dados ganham corpo, visibilidade, pertinência, numa palavra, realidade.

\section{A Igreja como comunidade humana}

Embora constitua uma comunidade religiosa, uma comunidade de fé, a Igreja não deixa de ser uma comunidade humana. O que, de fato, constitui uma comunidade humana? Segundo alguns autores é uma comunidade que chega à sua realização pela conjunção de quatro componentes estreitamente relacionados entre si. Estes elementos constitutivos devem ser comuns a todos os seus membros. Primeiramente uma experiência partilhada por todos, o que implica situações existenciais com seus desafios atingindo a todos, plasmando assim uma história comum. Em seguida, seus membros devem dispor de compreensões e avaliações da realidade também comuns, inclusive das experiências acima mencionadas. E, finalmente, se requerem compromissos e decisões comuns em vista de valores comuns para que esta comunidade se torne efetiva. Deste modo uma comunidade não se define espacialmente, mas nasce e morre na medida em que uma comunidade de experiência, de compreensão, de juízo e de decisão nasce e morre.

9 N. GREINACHER, "Soziologische Aspekte des Selbstvollzugs der Kirche", in F.X. ARNOLD (org.), Handbuch der Pastoraltheologie: praktische Theologie der Kirche in ihrer Gegenwart, v. I, Freiburg, 1964, p. 418s.

${ }^{10}$ Esta é a crítica feita por P. Berger à expressão "creio na santa Igreja católica" do Credo. Ver, deste conhecido autor, Questions of Faith: a skeptical affirmation of Christianity, Oxford, 2004, p. 130-143. 
Por outro lado, tais elementos comuns não surgem de repente, nem brotam do nada. Pois se é comunidade humana, é, constitutivamente, uma comunidade de sentido e de valor, um avez que ela se compreende e se constitui no interior de uma linguagem recebida, de um horizonte cultural transmitido, de uma interpretação determinada dos eventos, que facilita e, ao mesmo tempo, limita sua compreensão da realidade e sua escala de valores. É através desta "matriz", recebida de seus antecessores, que cada membro procura distinguir o verdadeiro do falso, o bom do mau. Portanto habitamos um mundo social criado por outros, com sua linguagem, símbolos, papéis e instituições, realizações políticas e econômicas. E só no interior deste horizonte cultural histórico, contextualizado, encaramos, entendemos e avaliamos a realidade.

O gesto de Deus em Jesus Cristo, suas ações, suas palavras, sua morte e sua ressurreição representam o componente transcendente da comunidade eclesial, que interpela, convoca, possibilita, agrega e vivifica. A pessoa de Jesus Cristo abre assim para a humanidade um novo quadro interpretativo da realidade, que irá possibilitar experiências comuns, compreensões comuns, juízos comuns e compromissos comuns, constituindo assim a Igreja. Esta estará igualmente dotada de linguagem e símbolos próprios, de papéis e instituições peculiares, de cosmovisões e valores específicos. Assim, a Igreja é uma comunidade com identidade própria ao lado de outras comunidades humanas.

Enquanto tal, ela representa uma nova comunidade caracterizada por novas experiências, insights, juízos e práticas, como resposta à interpelação de Deus em Jesus Cristo. Deste modo, sua realidade visível torna-se o sinal e o efeito da ação salvífica de Deus na história, assim como se dera na Palestina na pessoa de Jesus, em suas palavras e ações. Temos assim a manifestação social desta modalidade de vida inaugurada por Jesus Cristo, que se distingue de outras, interpelando-as a viverem o desígnio de Deus para a humanidade. A Igreja apresenta socialmente para seus membros, ou para os de fora, os sentidos e os valores cristãos, e mais concretamente, a pessoa viva de Jesus Cristo, nossa salvação. Neste sentido ela é sinal salvífico para o mundo (LG 1).

Podemos caracterizar o que acima afirmamos como a dimensão objetiva da Igreja, na qual está presente a pessoa e a vida de Jesus Cristo, bem como as Escrituras, a Tradição, os dogmas, a liturgia, os santos, etc. Contudo tais componentes só constituem de fato a Igreja na medida em que são recebidos e apropriados por cada geração de cristãos. Só então tais princípios ganham vida, entram na realidade social, emergem para seus contemporâneos no discurso e nas ações dos cristãos, comprovam-se em gestos de responsabilidade histórica. Estamos às voltas com a dimensão subjetiva da Igreja. Esta dimensão nunca é geral, teórica ou uniforme. Pois as pessoas que crêem, esperam e amam são pessoas concretas, vivendo em contextos 
determinados, expostas a desafios próprios, confrontadas com outras diferentes visões da realidade. Numa palavra, são seres históricos, sendo que só no interior desta sua história poderá ser dada a resposta a Deus pela fé vivida.

Ao proclamar e viver o Evangelho num contexto particular e numa concreta época histórica, esta proclamação e esta vivência deve ser salvífica para os desafios desta situação e deste tempo. Caso contrário, não seriam entendidas, nem pertinentes, nem atuantes. E a Igreja não seria sinal para o mundo, oferecendo-lhe uma nova modalidade de vida. Com isto afirmamos que a própria comunidade cristã se constitui e se autocompreende com as representações mentais, as estruturas de pensamento, as categorias sociais, presentes e atuantes em seu respectivo contexto sociocultural. Perder de vista esta realidade pode significar absolutizar o relativo, eternizar o histórico, fixar o provisório, impedir novas configurações eclesiais.

Quando acontece, este fato repercute danosa e negativamente para dentro da própria Igreja, que não mais consegue transmitir o que crê e o que vive ( $D V$ 8) para seus contemporâneos. Entretanto, é necessário que estes possam captar sua proclamação e aderir à sua mensagem, tornando-se, por sua vez, Igreja. Deste modo podemos dizer que a Igreja gera a si própria a cada dia ${ }^{11}$. Se esta autoconstituição da Igreja na história terminasse, a Igreja acabaria por deixar de existir. Com outras palavras, o que sustenta a Igreja é a fé, a esperança e a caridade de seus membros, fruto da ação salvífica do Deus de Jesus Cristo através de seu Espírito ${ }^{12}$.

Não nos deve admirar, portanto, que a Igreja, no curso da história, tenha assumido elementos de variados contextos socioculturais para proclamar a Boa-Nova, ou que tenha se apropriado de componentes institucionais à mão para se organizar como comunidade. Fundamental é que toda esta assimilação esteja, de fato, a serviço de sua finalidade salvífica. De qualquer modo, este fato já nos abre a possibilidade de examinar se certa ausência de resultados na ação apostólica da Igreja resulte simplesmente de má vontade ou falta de fé de uma geração, ou talvez de elementos institucionais e lingüísticos de outras épocas, que mais vedam do que deixam entrever sua dimensão transcendente, como mistério de Deus na história.

\section{A Igreja como comunidade na história}

As experiências salvíficas são fundamentais para a Igreja, pois são elas que confirmam existencialmente a ação do Espírito de Cristo entre os seres humanos. Contudo, estas experiências só são consideradas salvíficas e cris-

${ }^{11}$ BEDA, O VENERÁVEL, "Nam et Ecclesia cotidie gignit Ecclesiam" (PL 93,166d).

12 TOMÁS DE AQUINO, Comentário aos Colossenses, c.I,1,5: "Fides est sicut fundamentum, ex cujus firmitate tota firmatur ecclesiae structura". 
tãs porque são lidas na perspectiva hermenêutica aberta por Jesus Cristo, já que toda experiência humana é experiência interpretada. A linguagem da comunidade eclesial precede a adesão pessoal, como o quadro interpretativo em cujo interior esta adesão se torna compreensível e acessível. Há aqui uma interação mútua. A visão cristã da comunidade possibilita à experiência poder se dar e se expressar como experiência salvífica. A experiência salvífica, por sua vez, fundamenta a expressão eclesial e, gozando de certa autonomia, a faz progredir sempre que excede a expressão tradicional. De qualquer modo a comunidade eclesial se apresenta como uma comunidade de linguagem.

Deve-se observar que linguagem tem aqui um sentido amplo, pois inclui não só enunciados e doutrinas, mas também imagens e símbolos, gestos e ritos, pastorais e espiritualidades, biografias edificantes e ações históricas, palavras e sacramentos. Tudo isto constitui o horizonte eclesial que, à luz do evento Jesus Cristo, interpreta, avalia e aciona a resposta dos cristãos à interpelação de Deus. A fé é uma realidade teologal, mas que só se realiza eclesialmente, ou, com outras palavras, institucionalmente. De fato, a comunidade dos fiéis não se constitui como tal prescindindo de formas institucionais.

Além do componente institucional, a Igreja só realiza sua finalidade de ser sacramento do Reino de Deus acontecendo na história, na medida em que realmente viva os valores evangélicos. Os compromissos comuns da comunidade são componentes constitutivos da mesma, como vimos anteriormente. A fé deve ser uma realidade vivida, no confronto com outras comunidades humanas, com outras cosmovisões e com outras práticas sociais. A Igreja só é sinal de salvação através de uma linguagem performativa, através de ações significativas para uma geração, através de tomadas de posição diante de seus desafios existenciais e sociais. Só assim ela manifesta, na força do Espírito que a anima, a pertinência salvífica da pessoa de Jesus Cristo, de suas palavras e de suas ações. Só assim ela pode ser sacramento da salvação para a humanidade. A Igreja só é Povo de Deus, Corpo de Cristo e Templo do Espírito na medida em que homens e mulheres acolhem e estruturam suas vidas em torno da Palavra de Deus, no acolhimento da ação salvífica do Espírito Santo, constituindo assim comunidades cristãs. Através destas, a ação salvífica divina se faz atuante e presente na história.

Já se escreveu que a sociedade é uma produção humana, a qual ganha uma realidade objetiva para gerações posteriores, que por sua vez são por ela socializadas ${ }^{13}$. Homens e mulheres, movidos pelo Espírito de Deus e obedientes à pregação dos apóstolos, partilharam experiências, sentidos e práticas comuns, constituindo-se assim numa comunidade cristã. É neste sentido que a Igreja pode ser dita também uma produção humana. Ela é

${ }^{13}$ P.BERGER-TH.LUCKMANN, A construção social da realidade, Petrópolis, $1973^{4}$. 
também uma realidade objetiva, anterior à pessoa que a encontra no curso da história, dotada de uma identidade que a distingue de outras comunidades e à qual cada um pode aderir. Em seguida à sua adesão deve a pessoa assimilar a linguagem e a prática da Igreja, ganhando assim uma nova identidade social, a identidade cristã. Mas também se torna sujeito ativo e participante bem como membro constitutivo desta realidade objetiva, visível na história como comunidade originada por Jesus Cristo ${ }^{14}$.

E como cada geração, enfrentando-se com cenários diferentes, viverá experiências próprias, num horizonte sociocultural peculiar, não é de se admirar que a comunidade venha a expressar sua fé, esperança e caridade correspondentemente a seu contexto concreto. É neste sentido que se afirma que a Igreja se autoinstitucionaliza no curso da história. Daqui, devido à mútua interação entre Igreja e sociedade, a necessária sucessão de configurações eclesiais ao longo dos séculos. A Igreja muda para conservar sua identidade e sua finalidade. Um juízo sobre uma determinada forma institucional eclesial exige sério conhecimento do contexto sociocultural onde se constituiu, sob pena de cairmos em avaliações errôneas baseadas em nosso contexto atual.

Por outro lado, considerado seriamente o contexto de outrora, a distância no tempo com relação a acontecimentos do passado pode nos ajudar a melhor perceber certas unilateralidades, deficiências e juízos precipitados na visão tradicional que nos foi legada. Podemos constatar isto em nossos dias com relação ao cisma do oriente e à reforma protestante. Já Congar observava sabiamente que cada vez que ia diretamente às fontes encontrava outra realidade do que a que lhe haviam ensinado ${ }^{15}$. Esta observação não exclui, entretanto, que alguns aspectos da mensagem cristã tenham sido mais acentuados devido à situação encontrada. A compreensão que a Igreja tem de si mesma é uma realidade histórica, bem como suas expressões e instituições. Ênfases exageradas ou silêncios ilegítimos ocorreram como nos ensina a história.

Além disso, como não só a ação do Espírito Santo, mas ainda a força da concupiscência está presente na comunidade eclesial, muitas destas configurações de cunho histórico refletem também esta realidade ambígua. Busca de prestígio, vontade de poder, necessidade de segurança, reconhecimento social, misturam às motivações propriamente religiosas e não são facilmente percebidas num-se primeiro momento.

Do ponto de vista institucional haverá uma crise na comunidade eclesial (como, aliás, em outros grupos sociais como família, escola, classe política) sempre que as experiências, as compreensões, as avaliações e os compro-

${ }^{14}$ J.A. KOMONCHAK, op. cit., p. 165s.

${ }_{15}$ Y. CONGAR, Chrétiens en dialogue, Paris, 1964, p. 125s. Citado por H. LEGRAND,

"Yves Congar (1904-1995): une passion pour l'unité", NRTh 126 (2004) 535. 
missos comuns dos membros da comunidade não mais se encontrem na instituição concreta que lhes foi legada. Suas expressões e práticas, formulações doutrinais e morais, dinamismos e estruturas não se vão mais adequando à realidade vivida pelos membros da comunidade, a qual apresenta novos desafios, novos contextos, novas mentalidades, que exigem uma nova linguagem em sentido amplo.

\section{A institucionalização da Igreja no curso da história}

Não pretendemos demonstrar como as afirmações precedentes se deram ao longo da história da Igreja, pois para isso teríamos que percorrê-la toda, apontando em cada época o papel desempenhado pelos fatores socioculturais, políticos e mesmo econômicos na autocompreensão eclesial, nas teologias e nas instituições correspondentes, comprovando-se assim que a realidade concreta e histórica do que chamamos Igreja católica não desceu pronta do céu, nem se encontrava em toda a sua múltipla complexidade na mente dos primeiros cristãos. Esta tarefa começa a se tornar um tema de estudo ultimamente, graças ao trabalho pioneiro e magistral de Congar ${ }^{16}$. Portanto, aqui buscamos tão somente oferecer alguns exemplos de cunho histórico, sem pretender abordar o tema exaustivamente. Propositadamente não enfatizaremos os elementos da comunidade eclesial, provenientes da revelação, responsáveis, em última instância, por sua identidade. Tais seriam: a proclamação do Evangelho, a resposta da fé, a ação do Espírito Santo, a celebração eucarística, o ministério apostólico. Pois aqui nos interessa examinar as diversas configurações destes elementos no curso da história. O que não implica querer reduzi-las a meros produtos resultantes dos condicionamentos de cada época.

Enquanto comunidade salvífica, isto é, enquanto comunidade encarregada de viver e proclamar a salvação trazida por Jesus Cristo, não podia a Igreja furtar-se ao diálogo com seu contexto sociocultural e político, uma vez que exatamente nele viviam não só os cristãos, mas ainda aqueles a serem evangelizados. Era, portanto, fundamental conhecer a linguagem dominante, as práticas sociais, os desafios da época, para se fazer entender e ser significativa para a vida real de seus contemporâneos. Além disso, estas eram as categoriais mentais disponíveis para a própria comunidade enten-

\footnotetext{
${ }^{16}$ Teríamos que citar toda a vasta obra histórica deste teólogo, mas indicamos apenas sua síntese em L'Église de saint Augustin à l'époque moderne, Paris, 1997². Ver ainda G. LAFONT 1 e do mesmo autor, Imaginer l'Église catholique, Paris, 1995 (aqui LAFONT 2).
} 
der a si própria. Por serem históricas e limitadas, abriam algumas perspectivas e fechavam outras.

Deste modo, a influência do platonismo irá enfatizar, na linha de uma anagogia espiritual, um voltar-se para Deus mais vertical, em detrimento do elemento temporal, que terá na teologia de S. Irineu de Lyon uma exceção. A revelação como processo histórico não é valorizada, já que a visão helenista considera a história como espaço do provisório e do limitado $^{17}$. Também a influência do helenismo se fará sentir na visão de um Deus-Uno, transcendente, responsável por tudo, ao qual o ser humano busca se unir. Para tal, existem os intermediários do culto e os mediadores do político, constituindo-se assim uma dupla hierarquia circunscrita ao mundo sagrado e ao mundo profano, que terá conseqüências para a configuração religiosa e política da sociedade, e que irá perdurar por séculos na cristandade ocidental. O príncipe e o sacerdote estão assim encarregados de levar os seres humanos deste mundo mau para o mundo bom, cada um conforme seu âmbito de ação ${ }^{18}$.

Outro exemplo histórico que poderia ser mencionado diz respeito à influência do modelo político do império romano sobre a instituição eclesial, embora a autoridade na Igreja não o copie, mas seja vista em sua perspectiva, e também, por outro lado, tenha tido influência sobre as estruturas do Estado $^{19}$. De fato, a ameaça bárbara e ariana diante do enfraquecimento do poder político do império, levaram os papas a defender seus fiéis, ganhando assim um poder maior, também de cunho político, como tiveram figuras do porte de Leão Magno e de Gregório Magno. E, mais tarde, a coexistência de duas autoridades com plenos poderes, não deixou de gerar conflitos. Teoricamente caberia a cada uma delas um diferente âmbito. De fato, tanto o papa como o imperador, deviam zelar pela salvação eterna de seus súditos. Assim os príncipes preocupavam-se em assegurar condições de vida cristã (intervindo, por exemplo, nas nomeações episcopais), enquanto os papas procuravam controlar a vida política em vista de promover o Reino de Deus. Com a diminuição do poder externo dos papas nos séculos seguintes, fato este que liberta progressivamente a Igreja de uma estrutura própria de uma cristandade, ganha o sucessor de Pedro maior autoridade no âmbito intra-eclesial, até se apresentar como pastor univer$\mathrm{sal}^{20}$. Hoje alguns questionam se o conflito do papa com o imperador não tenha pesado mais na figura do sucessor de Pedro do que afirmavam as fontes da Escritura e da Tradição ${ }^{21}$.

${ }_{17}$ LAFONT 1, p. 50s; 89s.

${ }^{18}$ LAFONT 2, p. 21-23; 24-29.

${ }^{19}$ Ibid., p. 61-64.

${ }^{20}$ Ibid. p. 64-73.

${ }^{21}$ LAFONT 1, p. 118-120. 
A reforma, empreendida pelos papas para combater a simonia e o nicolaísmo, também trará conseqüências na ordem institucional, as quais perduram até nossos dias. O primado pontifício sai reforçado, o ideal de um sacerdócio casto, desinteressado e santo para instruir o povo e administrar os sacramentos começa a se concretizar, o controle da reta doutrina, em nome do papa, enfatiza a verdade como caminho salvífico, os sacramentos aparecem mais em seu aspecto medicinal numa sociedade pessimista do ponto de vista moral, os fiéis são vistos como pouco instruídos requerendo uma estrutura hierárquica firme, os bispos perdem força por pertencerem ao mundo dos nobres com seus interesses próprios, reafirmando a primazia na Igreja do universal sobre o particular. A configuração gregoriana permanecerá na época medieval e moderna ${ }^{22}$. A teologia política medieval dava ao papa os meios de intervir em vista da salvação das almas, ameaçadas também pelo emergir de novas nações e pela submissão dos bispos aos príncipes. Num contexto de cristandade este poder pontifício não se limitava somente ao âmbito espiritual ${ }^{23}$.

Deste modo, uma eclesiologia jurídica se desenvolve no ocidente, caracterizada pelas teses de direito público eclesiástico, a qual convive e depois toma o lugar de uma eclesiologia mistérica ou sacramental. O papado será concebido como um poder entre outros poderes. As estruturas de catolicidade horizontal (via conciliar) serão substituídas pelas de catolicidade vertical (centralização na cúria romana), aparecendo a Igreja, em alguns textos da época, como uma grande diocese, sendo os bispos vigários do papa pela impossibilidade de tudo governar. Assim tem lugar uma crescente centralização que vai de par com uma progressiva uniformidade jurídica e litúrgica. A própria noção de Igreja sofre uma mudança semântica. Ela se limita a seus membros eclesiásticos e a sua estrutura, distinguindo-se assim da cristandade ou do povo cristão ${ }^{24}$.

Importante para se entender a atual configuração eclesial foi o choque das autoridades eclesiásticas com a modernidade. Já incipiente no século XIII devido à própria compreensão e estrutura da Igreja de então. Esta tinha bem presente seu objetivo de levar a salvação à humanidade, livrando-a da condenação eterna. Partia de uma antropologia debilitada, pois a liberdade humana se encontrava enfraquecida pela propensão ao pecado. Daí, a importância dos que detinham o poder eclesiástico, especialmente do papa, para mediatizar o perdão dos pecados e a verdade salvífica. Já a modernidade parte da razão humana, tanto na compreensão da fé (poden-

${ }^{22}$ Ibid., p. $363 \mathrm{~s}$.

${ }^{23}$ Ibid. p. 344

${ }^{24}$ CONGAR, op. cit., p. 89-122.

${ }_{25}$ Outros fatores históricos e políticos também tiveram seu peso. Ver R. RÉMOND, Religion et Société en Europe: la sécularisation aux XIX et XX siècles 1789-2000, Paris, 2001. 
do aí errar) como no âmbito sócio-político, dando espaço à liberdade e à responsabilidade (podendo aí dissentir). Em conseqüência disto se compreende, em parte ${ }^{25}$, a reação negativa da hierarquia que via na modernidade um perigo para a salvação dos homens, respondendo a este desafio com um controle intenso e vigilante ${ }^{26}$. Embora já Santo Tomás oferecesse uma síntese harmônica da relação fé e razão, o papado irá preferir a linha franciscana de São Boaventura, como orientação teológica que preservava melhor a configuração gregoriana da Igreja.

Diante do advento dos múltiplos soberanos na linha do império teocrático de outrora, a Igreja responde criando o Estado Pontifício como entidade política, justificado teologicamente pela teoria da Igreja como sociedade perfeita, superior a qualquer nação quando se tratasse de questões religiosas. Para isso acentua ainda mais a centralização administrativa e financeira, e reforça que o primado do papa provém imediatamente de Deus. Isto explica também que, depois do Concílio de Constança, o papado tenha mais facilidade de tratar com regimes monárquicos (através das concordatas) do que com estruturas de poder mais democráticas ${ }^{27}$.

Diante da cultura moderna e da reforma protestante, as autoridades eclesiásticas controlam fortemente a reflexão teológica e mantêm distante dos católicos os instrumentos da cultura da época através da inquisição e, sobretudo do index librorum. O magistério eclesiástico atribui-se não só, como no passado, o controle da fé, mas ainda ser a fonte privilegiada desta fé. Os catecismos para os párocos ou as nascentes encíclicas concretizam apenas dois níveis desta concepção, que igualmente reserva para si o monopólio da interpretação e da práxis cristã. Nenhum espaço livre é deixado ao exercício sensato da inteligência da fé. A razão é assim abandonada a si própria, regida apenas por si mesma, sem referências que lhe imponham limites e corrijam unilateralidades, acabando por gerar uma modernidade racionalista cujas conseqüências sentimos pesadamente em nossos dias ${ }^{28}$.

Devemos, de um lado, avaliar positivamente a posição defensiva da Igreja diante de transformações socioculturais e políticas que ameaçavam a salvação dos cristãos. Mas, de outro, devemos também apontar o que resultou da falta de diálogo com a sociedade em mutação, que não contou com o humanismo cristão, ao se compreender e ao se organizar. Daí ter surgido um racionalismo irreligioso e forte descristianização, sobretudo entre os mais cultos ${ }^{29}$. Tanto o fim da modernidade quanto o fim da era

${ }^{26}$ LAFONT 1, p. 196.

${ }^{27}$ Ibid., p. 220s.

${ }^{28}$ LAFONT 2, p. 30-35.

${ }^{29}$ LAFONT 1, p. 372s.

${ }^{30}$ Ibid., p. 82-84. 
constantiniana apontam uma insuficiência na sociedade e na Igreja ${ }^{30}$. As conseqüências negativas de certa racionalidade pretensamente absoluta, caracterizadas e sofridas por nós sob o rótulo de pós-modernidade, bem como a indiferença de nossos contemporâneos diante da autoridade eclesiástica, da proclamação salvífica e da própria Igreja, demonstram sobejamente a necessidade e a urgência de uma configuração eclesial que parta, embora lúcida e criticamente se necessário, da realidade atual com suas referências culturais, linguagens, aporias, indigências, conquistas e desafios. Para alguns, a Igreja se antecipou mesmo à sociedade com a convocação do Vaticano II, que antecedeu o maio de 1968.

Estes dados históricos, embora breves e incompletos, procuraram apenas confirmar a abordagem sociocultural apresentada na primeira parte deste estudo, evitando se adentrar por questões mais concretas em discussão hoje, como o primado petrino, os ministérios na Igreja, a maior participação dos leigos nas decisões, as condições para uma séria reflexão teológica, para só citar alguns. Mas deixaram entre parênteses uma questão mais central e sempre presente ao longo da história da Igreja, embora se ponha hoje de modo mais agudo. Se não podemos ter uma Igreja desencarnada, que prescinda dos seres humanos e, conseqüentemente, das culturas, instituições e práticas sociais dos mesmos, as quais experimentaram e continuarão a experimentar mudanças ao longo do tempo, como distinguir nela o que é meramente contingente do que lhe é essencial? O tema é vasto e abarca diversas áreas da eclesiologia: tradições autênticas ou não, recepção teológica, papel da autoridade, consenso na fé, papel da ortodoxia e da ortopraxía, etc.

\section{Considerações finais numa perspectiva ecumênica}

\section{Conseqüências no interior da Igreja católica}

A exposição até aqui apresentada demonstra a insuficiência de uma visão monofisita, supranaturalista, dogmaticista, numa palavra, reducionista da Igreja. Como seria, aliás, igualmente uma interpretação da mesma, apenas em chaves históricas ou socioculturais. A resposta dos cristãos à proclamação do Evangelho, ou à interpelação da pessoa de Jesus Cristo, acontece sempre no interior de situações existenciais e sociais determinadas, em contextos históricos concretos, que acabam por configurar tal resposta, individual e socialmente, conforme os componentes culturais e sociais destes respectivos contextos.

Tais configurações históricas da fé são não só legítimas, mas necessárias para que a pessoa e a mensagem de Jesus Cristo possa realmente ser ouvida, entendida e vivida por novas gerações. A inculturação da fé é um 
fenômeno tão antigo quanto a própria Igreja. Esta necessidade não se limita a horizontes e contextos socioculturais que explicam a rica diversidade de expressões da mesma fé na história do cristianismo, seja nas confissões de fé, nas liturgias, nas teologias, nas práticas devocionais, na piedade popular, pois a resposta cristã é despertada, iluminada e incentivada pela comunidade eclesial, por um grupo social caracterizado por experiências, crenças, juízos e compromissos comuns, que só existem na sociedade concreta em que vivem os cristãos.

Daí decorre que estes componentes comuns que fornecem identidade à Igreja não possam prescindir da conjuntura social e histórica onde acontecem. Não se trata de opor iniciativa salvífica de Deus e construção humana em detrimento da primeira. Afirmamos apenas que o componente transcendente da Igreja, a saber, a pessoa de Jesus Cristo pela ação de seu Espírito, só alcança realmente o ser humano inevitavelmente já enraizado numa cultura, numa sociedade, num contexto histórico. A identidade decisiva da comunidade eclesial provém de Deus. Confirmam-no as próprias expressões: Povo de Deus, Corpo de Cristo, Templo do Espírito Santo. Porém esta realidade teológica não existe a não ser indivise e inconfuse numa comunidade humana histórica.

E como as configurações eclesiais apresentam diversidades, tanto sincrônicas como diacrônicas, tanto geograficamente como temporalmente, surge inevitavelmente a questão pela necessidade ou não de se conservar tais diversidades, sobretudo se considerarmos que as mesmas surgiram em conjunturas históricas bem determinadas, não mais encontradas em nossos dias. Hoje esta questão se reveste de especial importância. Pois estamos bem conscientes que a atual configuração eclesial resultou também de opções históricas, corretas naquela conjuntura, mas que em novos contextos já não mais se justificariam. Poderíamos mesmo nos perguntar se a dificuldade encontrada pelas autoridades eclesiásticas em se fazer ouvir pela atual sociedade, mesmo reconhecendo a crise de valores nela presente, não estaria também no fato de que a atual configuração pressupõe uma cristandade não mais existente e um contexto de contra-reforma extinto pelo Concílio Vaticano II.

A atual sociedade pluralista em que vivemos não deixa de ter forte incidência nos membros da Igreja, levando-os não só a assumirem diversas conquistas da modernidade, como o respeito à liberdade e à responsabilidade próprias, mas também a questionarem tomadas de posição das autoridades que não apresentem justificação convincente. Como em outros setores da sociedade apenas o argumento de autoridade como tal não consegue mobilizar os ânimos, converter os corações e produzir frutos de vida eterna. A mensagem cristã se vê rodeada em nossos dias por uma pluralidade de fontes de sentido, religiosas ou não. É fundamental que ela apareça como um apelo significativo à liberdade, como uma opção em sintonia profunda com os anseios da pessoa humana, como um compromis- 
so na construção de uma humanidade mais justa e fraterna. Passamos de uma Igreja-cristandade para uma Igreja-comunidade, à qual se pertence por uma opção livre, tal como se deu no agir de Jesus e dos primeiros apóstolos (Dignitatis Humanae 11).

A maior participação de todos nos destinos da sociedade, que é um traço típico da atual cultura, não deixou de se refletir também no âmbito intraeclesial, recuperando verdades esquecidas no decurso da história, que tornaram a Igreja uma hierarcologia, como Congar costumava afirmar. $\mathrm{O}$ Concílio Vaticano II corrige esta falha já na Constituição Lumen Gentium ao partir de todos os fiéis como Povo de Deus (LG 9-12), ao afirmar a participação ativa dos leigos na liturgia (Sacrosanctum Concilium 14) e na missão salvífica do corpo eclesial (Apostolicam Actuositatem 3), seja no âmbito paroquial (LG 37), seja no âmbito diocesano (Chistus Dominus 27). Este espaço aberto pelo Concílio implica uma nova modalidade de governo na Igreja, na qual os responsáveis, sem abdicar de sua autoridade, permitam a participação de todos nas estruturas e nos objetivos pastorais ${ }^{31}$.

Poderíamos igualmente nos perguntar se as dificuldades de uma pastoral urbana não provêm, em parte pelo menos, de uma repartição de competências de cunho geográfico, na linha de uma autoridade sobre um território, que conseguiu "funcionar" bem antes do surgimento das grandes cidades. Nestas o espaço geográfico não tem a mesma importância de outrora. Pela diversidade cultural e social nele presente, pela necessidade de restringir os inúmeros e possíveis contatos primários, pelo decorrente imperativo de selecionar as pessoas e os grupos realmente "significativos". Hoje se procura a paróquia onde a pregação toca existencialmente, fortalece a fé e ilumina a práxis cristã no emaranhado confuso de uma sociedade em crise. O elo é mais pessoal do que territorial e exige um modo novo de congregar os fiéis.

Numa sociedade caracterizada por uma multiplicidade de discursos e já bastante descrente dos mesmos, ganha enorme importância o testemunho da própria experiência cristã. $\mathrm{O}$ modo cristão de vida, as práticas sociais geradas pelas convicções da fé, a capacidade de não se deixar envolver pela cultura individualista dominante, a solidez das referências de sentido e de ação em meio ao torvelinho das opiniões disparatadas, os gestos de amor e de justiça, de honestidade e de lealdade evangelizam bastante mais que apenas doutrinas ortodoxas ou planos pastorais bem elaborados. $\mathrm{O}$ cristianismo nasceu do testemunho de fé e de vida oferecido pelos primeiros discípulos, que remetiam por si só à ação salvífica de Deus na história. Não negamos a importância de expressões corretas da fé, nem a necessidade do elemento jurídico na Igreja. Parece-nos, entretanto, que a autentici-

31 J. KOMONCHAK, "The Significance of Vatican Council II for Ecclesiology", in P. PHAN (ed.), The Gift of the Church, Collegeville, 2000, p. 69-92; P.C. BARROS, "A eclesiologia do Vaticano II e o ecumenismo", in J. BIZON R. DRUBI (orgs.), A unidade na diversidade, S. Paulo, 2004, p. 77-104. 
dade de vida encontrada, sobretudo nas camadas mais humildes da população, as quais constituem a maioria do Povo de Deus, deveria ser mais valorizada, pois é nelas que está realmente acontecendo, embora não exclusivamente, o Reino de Deus ${ }^{32}$.

\section{Como discernir o constitutivo no histórico}

Este é o ponto mais difícil deste estudo. A Igreja se institucionaliza ao longo da história, mas sempre em estreita conexão com seu respectivo contexto, através do qual visibiliza a resposta humana à iniciativa salvífica primeira de Deus em Jesus Cristo. Alguns componentes socioculturais, perfeitamente clarividentes quando vistos no interior do seu respectivo contexto histórico, acabaram por moldar uma determinada configuração eclesial, o modelo gregoriano que perdurou por séculos e que, para muitos, representou a Igreja sem mais. Os historiadores justificam e explicam as opções tomadas no passado, sem negar que foram históricas e, portanto, contingentes. Outro contexto, outro desafio, outra reação dos responsáveis, outra configuração eclesial? Poderia a Igreja de Jesus Cristo receber configurações históricas diversas? Em meio ao patrimônio recebido, o que deve permanecer? Haveria um critério que possibilitasse um tal discernimento? Ou tal critério seria a própria história da Igreja? Ou a autoridade da Igreja?

Não é nossa pretensão aqui entrar nesta espinhosa questão em torno da constituição da verdade de fé na Igreja. Não se pode negar, no curso da história, uma concentração decisória com relação à verdade nas mãos da autoridade eclesiástica, sobretudo do papa. Um fator que fomentou tal processo foi certamente o desenvolvimento científico da modernidade e a emancipação da sociedade da tutela da autoridade eclesiástica. A perda de seu poder político na sociedade é compensada com o aumento de seu poder no interior da Igreja. Como contra-partida esta atribuía a si uma maior competência doutrinal, a ponto de se chegar, na definição do Concílio Vaticano I, a fazer entrar na noção de verdade cristã, não só o que foi por Deus revelado, mas também o que é proposto como tal pelo magistério eclesiástico (Denzinger-Schönmetzer 3011).

Deste modo, a questão da prova da verdade se desloca da fonte da verdade para a autoridade que garante esta verdade, como já observara Congar ${ }^{33}$. Assim acontece um distanciamento da prática tradicional do passado, que buscava no testemunho da Escritura e da Tradição os critérios da verdade,

\footnotetext{
${ }^{32}$ Certa insistência na adesão a proposições ou na submissão a normas canônicas não refletiria uma época de cristandade, esquecida de que o fundamento de tudo consiste no testemunho da ação do Espírito nos fiéis? Este esquecimento significa absolutizar verdades e obrigações, que não mais remetem ao mistério de Deus presente e atuante na Igreja. Ver LAFONT 2, p. 96 nota 1.

${ }^{33}$ Y. CONGAR, La Tradition et les traditions I, Paris, 1960, p. 237.
} 
aos quais se submetia a autoridade. Conseqüentemente o princípio formal da autoridade tem prioridade sobre as provas, fato este agravado pela diminuição do exercício de autoridade doutrinal por parte do episcopado em benefício de uma concentração deste múnus no bispo de Roma ${ }^{34}$.

O Concílio Vaticano II na Constituição Dogmática Dei Verbum libera a revelação de uma compreensão limitada a enunciados de fé, ao vê-la nos feitos e nas expressões salvíficas de Deus ( $D V$ 2). Ela é acolhida e vivida na fé ( $D V 3)$, transmitida pelos apóstolos e também por toda a comunidade que "em sua doutrina, vida e culto, perpetua e transmite a todas as gerações tudo o que ela é, tudo o que crê" (DV 8). Deste modo a totalidade do Povo de Deus, ungida pelo Espírito Santo, "apresenta um consenso universal sobre questões de fé e de costumes" ( $L G$ 12). Igualmente não é esquecida a dimensão escatológica, característica da verdade cristã, que relativiza qualquer formulação proposicional ou qualquer codificação jurídica como última palavra sobre a revelação. A verdade revelada se desvela pela contemplação, pela experiência, pela pregação dos pastores, de tal modo que "a Igreja, no decorrer dos séculos, tende continuamente para a plenitude da verdade divina" (DV 8).

Estas observações do Concílio Vaticano II nos abrem novas perspectivas para respondermos à questão sobre os critérios normativos da verdadeira Igreja de Jesus Cristo. Devido às mudanças de cunho institucional no decorrer da história aparece bastante problemático, seja apontar como critério uma das fases do desenvolvimento neotestamentário, seja partir da atual configuração, fortemente descrita com características doutrinais e jurídicas ${ }^{35}$. A sucessão apostólica, a qual dificilmente se comprova historicamente como a imaginávamos, não garante sem mais a legitimidade da atual configuração católica. Nem apenas a Palavra de Deus, que nos chegará já interpretada pela exegese histórico-crítica.

A identidade da Igreja deve ser buscada na pessoa e na obra de Jesus Cristo e, mais precisamente, naquilo que constituiu a razão de ser de sua vida: a proclamação e realização do Reino de Deus ${ }^{36}$. Tal como afirma o Vaticano II (LG 5). A Igreja, assumindo a existência qualificada de seu fundador expressa, visibiliza e proclama para o mundo o Reino de Deus, celebrando-o nos sacramentos, sobretudo, da eucaristia. Daí afirmar o mesmo Concílio que a Igreja só cumprirá seu sentido último de "sinal levantado", de "luz do mundo" e de "sal da terra" enquanto "viver profun-

${ }^{34}$ B. SESBOÜÉ, Le magistère à l'épreuve, Paris, 2001, p. 151-182.

${ }^{35}$ S. DIANICH, Chiesa in missione: per una ecclesiologia dinamica, Milano, $1987^{3}$, p.169-184.

${ }^{36}$ H.J. POTTMEYER, "Die Frage nach der wahren Kirche", in W. KERN; H.J. POTTMEYER; M. SECKLER, (orgs.), Handbuch der Fundamentaltheologie III, Freiburg, $2000^{2}$, p. $163-166$. 
damente a vida cristã" (Ad Gentes 36). Deste ponto depende sua credibilidade diante da sociedade humana.

Deste modo concluímos que também a configuração institucional da Igreja deve estar adequada à sua missão de anunciar e realizar na história o Reino de Deus. A história nos ensina que mudanças institucionais se deram em vista salvaguardar a liberdade de proclamar e viver a mensagem evangélica por parte das autoridades eclesiásticas. Naturalmente, por vezes, nelas estava também presente a vontade de poder, o medo, a vaidade, enfim, o pecado. Mas não podemos absolutizá-las por terem surgido na história em contextos bem determinados, que, talvez em outras situações, peçam outras formas institucionais $^{37}$. Talvez, mesmo, a diversidade das configurações eclesiais no mundo cristão tenha acontecido na busca de tornar o institucional (meio) realmente salvífico $(\text { fim })^{38}$.

A Igreja nasceu da experiência salvífica com Jesus Cristo, iluminada e aprofundada pela ação do Espírito Santo em Pentecostes. Aqui está a fonte não só da vivência cristã da comunidade eclesial, mas também a origem de sua configuração institucional. É fundamental não nos determos numa leitura apenas histórico-jurídica das estruturas eclesiais, como se pudessem, por si sós, se justificarem, prescindindo da causa do Reino de Deus. Aqui também nos é dado o critério decisivo para mudanças institucionais, a saber, a salvação de homens e mulheres. Ao levar a sério os contextos socioculturais onde vivem e querendo permanecer fiel a sua missão, a Igreja saberá adaptar sua realidade institucional, mediação de sua realidade mistérica e transcendente, a tais contextos. Deste modo ela não destrói o que sua consciência de fé lhe apresenta como determinação divina, mas a torna realmente eficaz e frutuosa numa outra situação histórica. Neste sentido podemos dizer que a história ensina à Igreja como se institucionalizar em vista de sua única missão. Daí poder se considerar a história eclesiástica como autêntica autocompreensão da Igreja ${ }^{39}$.

\section{Análise histórico-institucional e ecumenismo}

Toda a finalidade desta reflexão foi de procurar considerar mais atentamente a dimensão institucional da Igreja, gerada no curso da história, em vista de levar avante a missão que Deus lhe incumbiu, a saber, de proclamar e realizar ao longo dos séculos o Reino de Deus. Enquanto resposta humana à oferta salvífica divina em Jesus Cristo possibilitada pela ação do Espírito, dada não só individualmente, mas como um grupo social, se vê a

${ }^{37}$ P. HÜNERMANN, Ekklesiologie im Präsens: Perspektiven, Münster, 1995, p. 23.

38 O.H. PESCH, "Hermeneutik des Ämsterwandels?", in P. WALTER; K. KRAMER, G. AUGUSTIN, Kirche in ökumenischer Perspektive: Kardinal Walter Kasper zum 70. Geburtstag, Freiburg, 2003, p. 133-138.

${ }^{39}$ Ver H. WEILER, "História eclesiástica como autocompreensão da Igreja", Concilium 6 (1971) 805-810. 
comunidade dos fiéis condicionada por seu contexto sociocultural nas expressões doutrinais, nas práticas sociais, nas estruturas de organização, como também nas próprias matrizes mentais que pensam a verdade revelada.

Já observamos que a riqueza da fé cristã recebeu na história do cristianismo configurações diversas e plurais de liturgias, de organizações sociais, de práxis cristãs, de acentuações doutrinais, de sistematizações teológicas. Todas elas legítimas, enfatizando certas características da fé e deixando outras em segundo plano, testemunhando assim a impossibilidade de expressar e conter o mistério de Deus numa única configuração. Esta pluralidade já estava presente no Novo Testamento e continuou constante na história da Igreja. Mesmo as diferentes configurações institucionais das confissões no interior do cristianismo podem estar apontando para uma necessidade histórica inevitável que, neste caso, deveria ser mantida, pois as diversas configurações se equilibram e se complementam mutuamente.

Constatamos hoje que, no que toca ao núcleo da revelação cristã (Deus, Jesus Cristo, Espírito Santo, graça salvífica), há um acordo de base entre as confissões cristãs. Não negamos os inevitáveis enfoques e sistematizações diversas. Constatamos que o que nos divide diz respeito aos meios para se chegar a este núcleo salvífico, tais são a Igreja, os sacramentos, os ministérios, etc. Do que vimos até aqui a mediação histórica do mistério transcendente recebe forte impacto do contexto histórico onde se faz presente e atuante. Não poderiam certas divergências institucionais, e suas respectivas justificações doutrinais, serem vistas como expressões possíveis no contexto existencial e sociocultural onde brotaram? Neste caso, teríamos uma pluralidade de configurações legítimas, que não empobreceriam, mas pelo contrário, que enriqueceriam o balbuciar humano do mistério de Deus.

Não devemos ignorar que a própria história produziu configurações unilaterais, instituições mais mundanas que evangélicas, compreensões preponderantemente jurídicas da verdade cristã, acentuações exageradas devido a um contexto polêmico. O conhecimento da história da Igreja-instituição ajuda sobremaneira a se corrigir tais distorções. Por exemplo, João Paulo II reconhece que o papado "constitui uma dificuldade para a maior parte dos outros cristãos" (Ut unum sint 88), e que se deve "encontrar uma forma do exercício do primado que, sem renunciar de modo algum ao que é essencial da sua missão, se abra a uma situação nova" (ibid. 95). Esta observação desencadeou nas diversas Igrejas numerosos estudos sobre esta questão.

O critério que adotamos, baseado na missão eclesial em vista do Reino de Deus, equilibra uma perspectiva demasiado conceitual e jurídica do passado, presente mesmo no Vaticano II em textos justapostos à nova eclesiologia. Devemos evitar o relativismo histórico, mas igualmente o dogmatismo de expressões históricas enquanto tais, que pedem, para serem conservadas em sua verdade, que as formulemos diversamente. Toda a questão da inculturação da fé brota daqui. 
Também nos facilita que aceitemos uma constatação vinda da sociologia, que reforça a tese da unidade na diversidade, tal como vem sendo hoje proposta. Para o adepto de uma confissão, mais do que as questões especificamente teológicas que, em geral, ignora, tem enorme importância como sua comunidade reza, se organiza, administra o poder, celebra o culto, exerce a caridade e se insere na sociedade. Pois o indivíduo permanece sempre marcado pela Igreja onde foi religiosamente socializado. Hoje a diversificação das confissões se dá mais em nível institucional, embora ligada a razões teológicas. E é mais fácil a uma Igreja mudar sua orientação e evoluir seu discurso do que mudar suas estruturas e seu modo de exercer a autoridade ${ }^{40}$.

Devemos ser humildes ao tratar da verdade cristã. Ela pode na limitação da condição humana apenas apontar para o Mistério de Deus que a ultrapassa, pois ela tem o todo no fragmento, o eterno no histórico, o já no ainda não $(1$ Cor 13,12). Como toda verdade humana é, necessariamente, contextualizada; como toda verdade cristã é aberta ao futuro e à fidelidade ('emet) de Deus ${ }^{41}$. A história da Igreja nos ajuda não só a melhor compreendê-la, como também a não absolutizar o que nela se encontra de histórico e de relativo, embora constituam instrumentos para sua missão salvífica.

Mario de França Miranda, SJ, é doutor em teologia pela Pontifícia Universidade Gregoriana (Roma). Atualmente é professor de teologia sistemática na Pontifícia Universidade Católica (Rio de Janeiro). Foi membro da Comissão Teológica Internacional (Roma). Publicou entre muitos livros e artigos: Uma catolicismo desafiado: Igreja e pluralismo religioso no Brasil, São Paulo: Paulinas, 1996, e $O$ cristianismo face às religiões, São Paulo, Loyola, 1998; A salvação de Jesus Cristo: A doutrina da Graça, São Paulo: Loyola, 2004.

Endereço: R. Marquês de São Vicente, 389 22451-041 Rio de Janeiro - RJ e-mail: mfranca@rdc.puc-rio.br

40 J.-P. WILLAIME, La précarité protestante, Genève, 1992, p. 174s.

${ }^{41}$ Para um estudo mais em profundidade ver M. FRANÇA MIRANDA, "Verdade cristã e pluralismo religioso", Atualidade Teológica 7 (2003) 32-49. 